\title{
At kommentere Glas
}

\section{Offentlig forelæsning på konferencen »Glossing Glas«, Koldinghus den. 26. maj 2001}

Før vi starter, vil jeg gerne takke Madame Myriam Néchad fra Den Franske Ambassade for både hendes støtte til arrangementet og velkomst her i dag. ${ }^{1}$ Og før jeg takker alle andre, vil jeg gerne lige kommentere arrangementet: Jeg er her, som I lige har hørt, for at promovere fransk sprog og kultur - også selvom det sker på engelsk!

Sprogproblemet er særdeles relevant, når det angår Glas: Glas er ikke kun en meget fransk bog, men mit problem med bogen - og det har været et problem i lang tid - er følgende, hvad angår det at virke for fransk kultur og det franske sprog: skal jeg insistere på det faktum at denne bog er fransk fra ende til anden således at den vil forblive uoversættelig, eller skal jeg insistere på dens oversættelighed og på dens cirkulation og udbredelse til andre udtryksmåder/sprog? Det er det problem vi står overfor når vi har at gøre med vores nationale sprog. ${ }^{2}$ Skal vi udvide det franske sprogs område, idet vi poder, oversætter eller indgraverer andre sprog indenfor vores eget sprogs krop, eller vice versa?

Jeg føler en uendelig taknemmelighed overfor alle her, for jeres tilstedeværelse, og først og fremmest overfor Roy Sellars og Per Krogh Hansen og alle de andre deltagere der tog del i dette kollektive læseprojekt, som har været under forberedelse i flere år. Her til formiddag blev jeg igen virkelig

1. Jacques Derridas besøg i Danmark var delvis finansieret af den franske ambassade, hvis kulturattaché Myriam Néchad åbnede den offentlige del af konferencen. I åbningstalen beskrev Myriam Néchad arrangementet som et led i promoveringen af fransk sprog og kultur. Derrida undlod ikke at ironisere over dette forhold - konferencens sprog var nemlig engelsk.

Derrida havde ikke noget manuskript til forelæsningen, men talte frit (så frit som engelsk nu engang tillader en meget fransk tænker det) på baggrund af de indtryk konferencen havde sat hos ham. Foreliggende tekst er en redigeret og oversat transskription af en båndoptagelse. Alle noter er ved oversætter og redaktører.

2. Se også Derridas "Letter to a Japanese Friend« i Peggy Kamuf (ed.): A Derrida Reader: Between the Blinds, N.Y., 1991, p.270: "spørgsmålet omkring dekonstruktion er netop spørgsmålet omkring det at oversætte, og omkring forestillingernes/idéernes sprog.« 
forbløffet over generøsiteten, opmærksomheden og stringensen i de oplæg, læsninger og spørgsmål som blev fremstillet og diskuteret. Deltagelsen i seminaret har været både en stor udfordring og kilde til både glæde og taknemmelighed hos mig. Så hjertelig tak til alle.

Se, begyndelsen for mig var: hvordan kunne jeg tale om denne bog, som muligvis er min, uden at være narcissistisk eller fetichistisk? Her til formiddag har vi behandlet spørgsmålet omkring narcissisme og fetichisme - og spørgsmålet omkring modtageren. En af vanskelighederne ved at henvende mig til jer nu har at gøre med det faktum at man har sagt mig at nogle af jer, specielt personerne bag ved mig [i.e. panelet], er fortrolige med Glas, andre er mindre fortrolige, andre er slet ikke fortrolige med den; så jeg er nødt til at opfinde en måde at tale til alle på. Men vi ved at dette er umuligt, så jeg har forsøgt mig med transaktioner og kompromiser for at nå et eller andet.

Spørgsmålet omkring modtageren som blev rejst i formiddags, var et besynderligt spørgsmål: hvem er modtageren? Hver bog, hvert skriveri, hvert spor formodes at have en modtager. Vil vi være i stand til at afgøre hvem modtageren er når først bogen er udgivet, når først vi ved hvem der vil læse den, hvem der vil reagere, hvordan alle vil læse den, og hvem der vil kontrasignere den. Og jeg vil insistere på denne opfattelse af kontrasignaturen. Modtageren bør ikke kun være den der modtager eller læser eller passivt registrerer bogen, eller teksten, men én som er villig til at opfinde, ja, et helt sprog, en måde at italesætte på - en poetisk måde. Her til formiddag var der en der sagde at det at læse burde karakteriseres som poetisk, en måde at opfinde sin egen idiomatik.

Så hvem signerer bogen, hvem er denne formodede forfatter? Når det gælder det juridiske aspekt, er jeg den formodede forfatter: mit patronym, mit egennavn - jeg er den formodede forfatter af bogen - men ingen er så naiv at tro at jeg er den egentlige forfatter af bogen. Den virkelige forfatter er hvem som helst der kan læse den, kontrasignere den, modtage den og så videre. Så modtageren, som er delt i flere bøger, er på samme tid det endelige sted for bogens ansvarlighed. Derfor frygten for at tale narcissistisk eller på en fetichistisk måde om den bog der angiveligt er min - spørgsmålet om signaturen/underskriften er allerede tilstrækkeligt tematiseret i bogen.

På det forudgående møde, særligt i går efter at have hørt Geoffrey Benningtons oplæg ${ }^{3}$, diskuterede vi teorien om en generel fetichisme som er i Glas. Fetichen er noget der bliver attrået i en sådan grad at ingen kan tilegne

3. Geoffrey Bennington diskuterede i sit indlæg på konferencen Glas' tematisering af Freud og fetichen. Artiklen vil være at finde i den udgivelse af konferencematerialet som er undervejs på University of Nebraska Press. 
sig den - den er utilegnelig. Så teksten som sådan - og denne tekst mellem andre - er utilegnelig. Den er fælles ejendom; den tilhører ikke nogen - på trods af ønsket om at tilegne sig den. Så fordi den er utilegnelig, og først af alt for mig, kan jeg tale temmelig frit omkring den uden at blive mistænkt for at være narcissistisk eller fetichistisk. Spørgsmålet omkring signaturen: idet jeg går tilbage til det franske sprog (og mit fremme af det franske sprog), meget drejer sig om spørgsmålet om signaturen, som jeg på fransk staver seing, hvilket betyder 'seglet', altså beviset/aftrykket af signaturen, det at give et aftryk af ens signatur. Se, le sein er selvfølgelig også 'brystet', $S$-E-I-N, moderen. Spørgsmålet omkring moderen er et af denne bogs mange sei(g)ns: hvad er moderen, hvem er moderen, hvem er den overlevende moder, hvis moder, Genets moder, og så fremdeles? Altså, seing/sein.

Endvidere har vi le saint, S-A-I-N-T, det hellige, religionens historie, frem for alt i denne bog om religion. Faktisk blev bogen skrevet efter et seminar jeg afholdte om Hegel, et seminar om Hegels religionsfilosofi. Det vil sige at bogen hovedsagelig handler om religion - om ukrænkelighed, hellighed, le saint. Så denne serie af ord seing, sein, saint, som er homonymer, ikke synonymer, er ikke ment som et ordspil. Der er ingen ordspil i bogen, på trods af rygter om det modsatte, ingen ordspil overhovedet. ${ }^{4}$ Men jeg forsøger at retfærdiggøre den indre nødvendighed, den indre forbindelse mellem disse spørgsmål omkring signaturen, seglet, brystet, helgenen, ukrænkeligheden. Og min egen signatur er ikke så meget på omslaget af bogen, som indeni teksten; den er indgraveret og nedsunket, gået tabt og mistet på den måde mellem tekstens spalter. Og mere end én gang er den gået tabt! Hvordan mister man sit navn? Det er spørgsmålet, ikke hvordan man fejrer eller hvordan man tilegner sig sit navn, men hvordan mister man sit navn?

Vi ejer ikke vores navn, og heller ikke vores sprog. Sproget tilhører verden - selv når sproget ikke tilhører nationen, er det ikke en ejendom, og det samme gælder for navnet; derfor er mit problem med fornavnet og efternavnet indgraveret i teksten, og det spiller en vis rolle i teksten, f.eks. når jeg leger med ordet déjà: mine initialer er D-J, Jacques Derrida, déjà ('allerede'), og derrière ('tilbage'/'bagved'). Igen og igen går mit navn tabt i teksten. Før jeg går videre, lad mig da citere en passage, et eksempel på hvordan jeg bruger mit navn. Som I ved er bogen i to spalter, én der i princippet er tilegnet Hegel, den anden Genet. Og indenfor, i hver spalte, er der hvad man

4. Se »Proverb: 'He That Would Pun . .'«, Derridas forord til John P. Leavey, Jr. \& Gregory L. Ulmer: Glassary, Lincoln, Nebraska 1986, pp. 17-20. 
kalder inserts eller "judas ${ }^{5}$ - små vinduer med en anderledes typografi, en anden skrifttype. Stykket her er et indskud eller en judas fra side 68:

»Paraden bliver altid tilbage [derrière]. $\ll^{6}$

Og jeg er selvfølgelig nødt til at indskyde det franske ord derrière fordi mit navn ikke fungerer på engelsk.

"Derrière: hver gang ordet kommer først, hvis skrevet efter et punktum og med stort bogstav, var der et eller andet i mig som begyndte at genkende min fars navn, med gyldne bogstaver på hans grav, selv før han var der.»

Selv før han var der! Jeg er nødt til at tilstå noget overfor jer: denne bog blev skrevet to år efter min fars død, og naturligvis er der nogle spor af sorgarbejdet tilbage i teksten.

\section{"A fortiori da jeg læste Derrière le rideau [Bag Gardinet]}

Derriére, bagved, er det ikke altid allerede bagved [déjà derrière] et gardin, et slør, en vævning. En lodden tekst: »En af mine andre elskere udsmykker sit intime uld med bånd. En anden vævede engang en lillebitte krone af tusindfryd til spidsen af sin vens pik. En fallisk kult bliver glødende tilbedt i hemmelighed, bag gardinet [derrière le rideau] af lukkede lynlåse. Hvis en rig forestillingsevne, idet den benyttede sig af forstyrrelsen, gjorde brug af det, tænk bare på hvilke festivaler til hvilke planter og dyr vil blive inviterede -«

- bogen er fuld af planter og dyr, ikke på grund af religionen af blomster, men fordi spørgsmålet omkring dyr allerede da var vigtigt for mig -

"til hvilken dyr og planter vil blive inviterede - vil følge, og fra dem, over dem, hvilken åndelighed! Jeg arrangerer i Javas hår de fjer der om natten flygter fra den punkterede pude. Ordet 'kugler' [couilles] er en rundhed i min mund«(Tyvens Dagbog).»

Der er et andet citat fra Genet, omkring moderen, på side 116 i Glas:

5. Judas betyder i denne sammenhæng 'kighul' eller 'dørspion', men for at lade den betydningsfulde relation til Judas Iskariot bestå, lader vi det stå uoversat.

6. Jacques Derrida: Glas. Overs. John P. Leavey, Jr., \& Richard Rand, Lincoln, 1986. Herefter forkortet $G L A S$. Alle indskud i følgende citat er, hvor ikke andet er anmærket, fra teksten. 
»Disse papirer er deres grave. Men jeg vil føre deres navn videre gennem tiden. Kun dette navn vil være tilbage i fremtiden, berøvet dets objekt. Hvis jeg tager afsked med denne bog, forlader jeg det der kan relateres. Reste(r)n(e) [oa.: le reste] er ubeskrivelige. Jeg siger intet mere og går barfodet.«

Og derpå har vi moderen der igen og igen i afsnittet siger, 'Bliv!' (Reste!):

»Hun bønfaldt den der erstattede (the supplanter [o.a.]), om at blive inden i hende. »Bliv et stykke tid, " græd hun. Dermed var Touraine ikke længere befrugtet.«

Lige ved siden af slutningen igen, »Bliv!«»

Og så fremdeles: »Det er MODEREN«, »Jeg (følg)er moderen.«

Idet jeg ikke er i stand til - og jeg tror at det vil være nytteløst at forsøge - at læse indefra teksten eller tale om teksten selv, tænkte jeg at det ville være bedre at forsøge at vende teksten rundt en tid. Så det jeg vil gøre er at vende teksten rundt fra to synsvinkler og derpå tage fat på nogle af de skrevne spørgsmål som blev stillet til mig på forhånd. De to spørgsmål jeg særligt vil begunstige, er spørgsmålene omkring teknik og politik.

Denne bog, som blev skrevet i 1972-73 og udgivet 1974, udkom på et meget særligt tidspunkt i skrivningens, trykningens og distributionens teknik. På det tidspunkt var der ingen computere tilgængelige for folk som mig. Og jeg er sikker på at havde jeg haft en computer, havde jeg ikke været interesseret $\mathrm{i}$ at skrive på den måde. Jeg var nødt til at forlade mig på skrivemaskinen, og en meget almindelig én af slagsen, og indenfor teksten, hvilket er spørgsmålet vi har beskæftiget os med de sidste to dage, bliver spørgsmålet omkring teknik rejst igen og igen, og helt ærligt, så siger teksten på et tidspunkt at der ikke er nogen glas uden et vist maskineri, pas de glas sans l'interposition d'une machinerie - ingen glas (det vil sige: ingen klokke, intet sorgarbejde, ingen bog ved navn Glas) uden et vist mål af teknologi det vil sige: måden at dele, at gentage, at trykke og at beregne på. På et tidspunkt er der en hentydning til musik, musikalsk teknologi, orgelet, for eksempel, så bogen er som en maskine, en beregnende maskine som forsøger at simulere betydningen af at være en 'beregner' [calculator, 'lommeregner']. Teksten er en maskine der taler om en maskine, og den gør det muligt

7. Arrangørerne af konferencen havde samlet en række generelle spørgsmål til Derrida og Glas på skrift inden forelæsningen - se afsnittet $Q \& A$ nedenfor. 
på et meget bestemt tidspunkt i trykningens historie, af skrivningens teknologi. Bogen har en dato - i dag ville det være lettere, meget lettere, at skrive sådan en bog, og meget lettere for udgiveren at udgive den. Dengang var det ikke så let at få bogen læst og udgivet af en udgiver. $\mathrm{Og}$ jeg vil komme tilbage til disse spørgsmål omkring historien, den sociale, økonomiske og teknologiske historie indenfor et område i hvilket sådan en bog i en vis udstrækning havde været en del. Det vil sige dens tids teknologiske omgivelser.

Og så til bogens politik. Når jeg forsøger at svare på spørgsmålet omkring bogen i det institutionelle, det politiske i akademiet og det politiske i det at udgive, vender jeg selvfølgelig tilbage til politikken. Men lige nu vil jeg gerne se nærmere på det politiske som et tema der er på spil i denne bog.

I en af spalterne i bogen forsøger jeg at analysere Hegels filosofi omkring loven, omkring staten, omkring suverænitet og så fremdeles, men blandt mange læsere - og specielt mellem mine venner her bag mig - har der med god grund været stor opmærksomhed omkring det jødiske spørgsmål, omkring jødedommen. En person i panelet insisterede i sin læsning på at fremhæve den måde på hvilken nogle talmudiske tekster er skrevet på siden med spalter, indskud etc.; andre fremdrog med god ret Glas' tematisering af omskæringen; andre igen, og jeg mener også de har ret, pegede på mit problem med min egen jødiskhed. Men det som ikke blev fremstillet, og det er hvad jeg gerne vil fokusere på nu, er spørgsmålet omkring Palæstina og palæstinenserne og israelerne.

I spalten om Hegel beskæftiger jeg mig selvfølgelig indgående med Hegels behandling af jødedommen før kristendommen og hans undersøgelse af den brutale og uretfærdige behandling af Abrahams børn. Så det tema bliver behandlet i den Hegelianske spalte. Men samtidig - og ikke mange læsere lægger mærke til dette - refererer jeg til Genet der i modsætning til Hegel faktisk var min ven, og som var i live da jeg skrev denne bog, som han også læste. Dengang støttede Genet faktisk palæstinenserne, og da jeg skrev bogen, var han sammen med palæstinenserne i Libanon. Jeg refererer til dette i bogen et sted (pp.36-37), hvor jeg er i færd med at bekende min begejstring ved at skrive om Genet, for hvad vil der ske hvis han læser mig? Hvad sker der hvis man skriver om en ven mens denne er i live? Jeg udtrykker noget om ham, men han vil ikke synes om bogen, han vil kaste op (opkastning er et af bogens temaer). Jeg sammenligner Genet med en hest. Genêt på fransk, med en accent over det sidste 'e', er navnet på en hest, en blomst og en hest - det er måden hvorpå et fællesnavn bliver til et egennavn - og jeg skriver:

"») Vagten meldte mig, og jeg blev bragt ind foran forstanderen..." 
"Ikke for at standse en Genets [dvs. en hests, JD] karriere. For første gang er jeg bange, mens jeg skriver, som man siger, 'om' [oa: on] nogen, for at blive læst af ham. Ikke for at standse ham, ikke for at trække ham tilbage, ikke for at tøjle ham. I går lod han mig vide«-

Det er sandt, det er et faktum! En af mine nære venner kom tilbage fra Beirut og fortalte mig at han havde mødt Genet.

»I går lod han mig vide at han var i Beirut, mellem de krigende palæstinensere, omringede udstødte.»

'Omringede udstødte' - tingene har i virkeligheden ikke ændret sig særlig meget.

»Jeg ved at hvad der interesserer mig, finder altid (hans/dets) sted derovre, men hvordan skal man vise det? Han skriver næsten aldrig mere ..."

Det var en periode hvor Genet holdt op med at skrive. Det ville måske interessere jer at vide at Genet afbrød sit skriveri i 1966-67 efter at Abdallah Bentaga begik selvmord i 1964, og i årevis skrev han ikke noget. Han genoptog skriveriet tyve år senere, i begyndelsen af 80'erne, da han begyndte at arbejde med lige præcis palæstinenserne. Så:

»Han skriver næsten aldrig mere, han har begravet [enterré] litteraturen som ingen anden, han springer hvor som helst det eksploderer i verden, hvor som helst Europas absolutte viden står for skud, og disse fortællinger om glas, seing, blomst og hest burde få ham til at skide.

Hvor har han dog ret. Det er det jeg gerne vil vise ved at forvise jer så hurtigt som muligt til kanten af et bassin, et hav, hvor grækerne, jøderne, araberne og hispano-maurerne ankommer til en endeløs krig. Hvilket jeg også er«-

- eller 'je suis' (jeg præsenterer ikke mig selv som en jøde, men som en hispano-maurer) -

»Hvilket jeg også er, ved sporet (que je suis aussi, à la trace).«

Der er altså dette ikke bare politiske tema, men denne politiske gestus i bogen, som er blevet mere eller mindre ignoreret. Og den er politisk, ikke bare når det gælder den politiske kode - det vil sige, hvad man kunne kalde 
geo-politik - men den er også politisk når det gælder intervention indenfor institutionen, og specielt indenfor akademiet/læreanstalten og indenfor markedet, men jeg vender tilbage til disse punkter. Pointen er blot at påpege, at der er et politisk tema og en politisk handling af/i denne bog.

Den anden ting vi må fremhæve i dag, er følgende: dødsstraffen. Alle de temaer som kan siges at udgøre bogens matrice, havde jeg allerede behandlet i tidligere bøger, hvorimod temaet omkring dødsstraf blev udviklet og uddybet i årevis efter bogen blev skrevet. Det er derfor jeg er så taknemmelig overfor mine venner for at de har tilskyndet mig til at genlæse denne tekst, for normalt genlæser jeg ikke hvad jeg har skrevet. Men efter at have genlæst i det mindste dele af bogen, blev jeg slået af det faktum at jeg allerede da jeg skrev Glas var interesseret i det der i dag udgør min primære interesse i Nietzsche, spørgsmålet omkring dødsstraffen.

Som I ved, er dette et brandvarmt emne i verden i dag. Men før jeg siger noget mere om dette, vil jeg gerne lokalisere det sted i teksten hvor spørgsmålet omkring dødsstraf bliver nævnt; det er på p. 98-99 i Hegel-spalten:

»Princippet omkring indre ødelæggelse, hjemlig negativitet«

- selv sagt er spørgsmålet omkring familien og mishandlingen af børn også et tekstens hovedtemaer -

"griber ikke kun ind på dette specifikke tidspunkt indenfor familieøjeblikket. At blive udsat for døden er vilkåret for enhver etisk totalitet generelt set, her af folket.»

At blive udsat for døden er et vilkår for hvad Hegel kalder folket - og jeg fortsætter med at kommentere Hegel:

» realiteten sikrer doktrinen omkring dødsstraffen passagen fra kritikken af formalismen til positionen af absolut Sittlichkeit. I en fortolkning der er speciel for ham, tager Hegel igen en sag op som på den tid var temmelig udbredt/velkendt, velkendt for Rousseau og Kant, for eksempel: dødsstraffen er frihedens vilkår. Den kriminelle skelnes fra dyret, positioneres som et frit subjekt, tager sig eget navn på sig og så videre, idet at han løfter sig selv op over livet. Straffen er ikke en tvangsmæssig eller undertrykkende straf. Straffen, en anvendelse af den universelle lov, viser friheden hos de der gør brug af den, og de der underlægger sig den. Ved at han accepterer sin straf, sandelig ved at bede om den, ved at glorificere den, anerkender den kriminelle loven, og dermed er han fri. Dødsstraffen bærer til det absolutte denne manifestation af frihed. Lige- 
som kapitlet i Fanomenologien om »Uafhængighed og Afhængighed af Selvbevidsthed: Herreskab og Trældom« gør artiklen/paragraffen omkring Naturlov det at sætte det naturlige liv i spil til vilkåret for en fri subjektivitet.»

Jeg blev slået af dette fordi jeg nu i tre år har givet et seminar omkring dødsstraffen, hvor jeg begynder med det faktum - ja, det forbløffende faktum - at der ikke er nogen vestlig filosof som sådan der har modsat sig dødsstraffen, og vi er nødt til at tage hensyn til dette: hvordan kan det være at filosofien som sådan altid har været forbundet og på linje med princippet omkring dødsstraf? Og hvordan og hvorfor, og på hvilken måde, kunne vi i dag i en diskurs - i en operativ/fungerende diskurs - uddybe det der modsætter sig dødsstraffen, det der ville være stærkt nok til at se disse traditioner, denne vestlige tradition, i øjnene?

Det er hvad jeg forsøger at gøre i dag, for som I ved er dødsstraffen i dag i Europa - bogen handler mere eller mindre om Europa - blevet afskaffet. Man kan ikke træde ind i Det Europæiske Fællesskab (EU) uden at afskaffe dødsstraffen; det er grunden til at Tyrkiet ikke kan søge om at blive medlem af EU. Men vi ved også at ikke kun Kina og et antal islamiske og arabiske lande, men også USA opretholder dødsstraffen. Sidstnævnte ikke bare opretholder dødsstraffen, men gør i udstrakt grad brug af den. Og dette er et problem der ikke kun er åbenlyst tragisk og så fremdeles. Det er et problem vi ikke kan skelne fra alle de vigtige politiske problemer angående suverænitet. Der er ingen dødsstraf uden princippet omkring suverænitet, ikke kun nationalstatens suverænitet, men suveræniteten af de andre stater som har dødsstraf og så fremdeles; så problemet omkring dødsstraffen er problemet omkring suverænitet, hvilket er et af nutidens store geo-politiske problemer. $\mathrm{Og}$ et sted i teksten insisterer jeg på hvad jeg kalder la potence, 'potensen'/'kraften' [fransk også 'galge', o.a.], af teksten, det givne. Spørgsmålet i teksten er ikke kun spørgsmålet omkring døden, som præger alle mine tekster. Men hvad der er mere vigtigt, er spørgsmålet omkring dødsstraffen - dødsstraffen som en stor, uforanderlig lære af en filosofi der ikke kan skille sig selv fra den suveræne stat. Derfor er det jeg forsøger at gøre lige nu - og jeg mener at dette er kulminationen på Glas - ved dette seminar, lige præcis at dekonstruere dødsstraffens skafot: Denne konstruktion, dette skafot af suverænitetens geo-politiske princip - fordi suverænitet er et geo-politisk problem der handler om redegørelse, den eneste geo-politiske enhed i hvilken vi finder dødsstraffen, suverænitet og filosofien. 


\section{Q\&A}

Efter at have sagt disse ting om Glas - berørt problemerne angående teknologi, politik og så fremdeles - lad mig da forsøge at svare på spørgsmålene fra panelet. Det første spørgsmål lyder således:

»1. I »The Time of a Thesis: Punctuations« præsenterer du din samlede produktion indtil 1980 som en del af et forsvar for en doktorgrad ved Sorbonne. Du siger imidlertid at der eksisterer nogle mere eksperimenterende tekster - og dette inkluderer Glas - som er udgivet efter 1972 og som du ikke mener "uden videre er præsentable eller acceptable i forhold til universitetet som en institution«; dermed bliver disse tekster ekskluderede fra omtalte forsvar. Men du tilføjer med det samme at når det gælder Glas, sker denne frivillige eksklusion "på trods af den vedvarende stræben i denne bog efter grammatologiens projekt, det vil sige: diskussionen med Saussures teser omkring tegnets arbitrære natur og onomatopoetik så vel som med den Hegelianske Aufhebung, forholdet mellem det ubestemmelige, det dialektiske og den dobbelte binding, forestillingen om en generaliseret fetichisme, kraften af diskursen om kastration/ kastrationens diskurs mod en bekræftende udbredelse og mod en anden helhedens og delens retorik, gen-uddybelsen af en problematik der beskæftiger sig med egennavnet og signaturen, med testamentet og monumentet og mange andre temaer desforuden; alt dette var i sandhed en udvidelse af tidligere forsøg« (i Philosophy in France Today, red. Alan Montefiore, pp.45-46). Er Glas i dine øjne nu uden videre blevet præsentabel eller acceptabel i forhold til universitetet som institution, eller er der sider ved den der forbliver upræsentable, uacceptable og ufordøjelige?«

På grund af den måde den var skrevet på, var jeg, da bogen blev udgivet, klar over at en sådan bog ikke ville blive betragtet som normal hvad angår lige netop akademiske krav: Der var mere end én tekst, den var ikke lineær, og med sine to spalter blandede bogen en stor filosof med en slyngel, en sjover, en homoseksuel, en pro-Palæstinenser, en pornograf og så videre, kort sagt: en af mine venner; så jeg vidste at dette ikke ville være acceptabelt.

Forestil jer at jeg i min ungdom, uden endnu at have udgivet noget, havde foreslået denne bog til en forlægger, for ikke at tale om universitetet. Der er ingen tvivl om at svaret ville have været: NEJ. Jeg var altså nødt til i en vis grad at legitimere mig selv ved at udgive tekster der blev opfattet som acceptable (selv om jeg allerede med disse tekster forsøgte at smugle tekster ind der ikke var acceptable), tekster der kunne udgives og som blev opfattet 
som lødige af universitetsverdenen: om Husserl, for eksempel. Og det var kun efter dette at jeg kunne forsøge at sælge og udgive visse belastende bøger. Det er et spørgsmål om strategi. Man er nødt til at beregne det passende tidspunkt for at foreslå og udgive noget som de herskende kræfter indenfor akademiet eller den sociale struktur ville modstå, men på lige netop det tidspunkt hvor de ikke kan modstå tilstrækkeligt til at forhindre en publikation.

Selvfølgelig er der god grund til at modsætte sig udgivelsen af Glas: hvornår, hvor, i hvilken grad og hvordan? Det er grunden til at jeg ikke kan give et endeligt entydigt svar på dette spørgsmål: der findes visse steder, visse universiteter, hvor Glas kan læses og accepteres - hér, for eksempel. Men hér er ikke hvor som helst. Og hér er ikke kun dette universitet. Det der gjorde denne konference mulig, hvor tog det sin begyndelse? Cornell trak sig - ja, USA har en meget anderledes atmosfære i det akademiske liv end Frankrig og Europa har. Så det er meget individuelt; det er ikke blandt alle europæiske universiteter at bogen er blevet accepteret.

I den forstand er det ikke universitetet der er problemet; det er hvor i universitetet, hvor i omløbet mellem de heterogene områder vil et eller andet gøre modstand mod bogen, og hvordan kan vi mindske modstanden. Dette er selv sagt et uendeligt forløb fordi selv på et sted hvor bogen bliver modtaget uden censur, ved ingen i hvilken grad bogen kan blive læst på en effektiv måde. Det er altså et politisk problem indenfor hver institution der er på spil her: forlæggerne, modtagelsen, aviserne, medierne. I Frankrig kunne man for eksempel forestille sig TV-programmer der var åbne overfor romaner - i visse tilfælde selv overfor filosofibøger - men de ville selvfølgelig aldrig ofre et program på en sådan tekst som Glas. Der er derfor tale om en forhandling, en endeløs forhandling.

Hvis det udelukkende havde været en bog om Genet, ville svaret fra forlagene have været: ja. Det samme gælder hvis det udelukkende havde været en bog om Hegel. Der findes universitetsforlag der byder bøger om Hegel velkommen, selv denne bog, hvis Hegel-spalten altså var blevet udgivet for sig - det ville ikke have været et problem. Men når man smugler noget andet med ind, bliver det vanskeligt. Og det at smugle er et emne når det gælder Genet idet han på et tidspunkt i sit liv blev taget i at smugle (sig selv) over grænserne som en hemmelig immigrant uden pas - og ikke kun indenfor Europa og Mellemøsten, men også i USA. Da han var homoseksuel, kunne Genet officielt ikke rejse ind i USA, så han var nødt til at krydse grænserne i al hemmelighed da han ville hjælpe De Sorte Pantere i slutningen af 1960erne.

Man er altså nødt til at smugle - det franske ord for smugling er contrebande, og contrebande betyder også 'bind(ende)', 'trældom', 'banding 
erect'; så ordene bande, contrabande, bandier er meget aktive i teksten Genet med Hegel, eller Hegel med Genet. Og nogle gange taber man på begge sider. Nogle gange ville de personer der er interesserede i Genet, ikke læse bogen fordi de ikke er interesserede i Hegel - måske ser de ham som en frygtelig digression; og på den anden side har de personer der er interesserede i Hegel, måske ikke lyst til at læse Genet. Altså læser de kun den ene spalte. At en række læsere kun læser den ene spalte, kan jeg bevidne - og jeg er fuldt ud tilfreds med dette.

Det andet spørgsmål:

"»». . . 'opgaven overrasker/forbavser mig' . . ."(Glas 26la, citerende Hegel). Er der noget der overrasker dig ved Glas efter at have genlæst bogen med henblik på denne lejlighed [i.e., mødet på Koldinghus]? Er det noget ved selve symposiet der har overrasket dig?«

$\mathrm{Nu}$ er det sådan at der aldrig sker noget - ikke for mig, ikke for nogen overhovedet - som ikke er en overraskelse. Forestillingen om overraskelsen er det essentielle ved begivenheden, begivenheden må af nødvendighed være en overraskelse. Hvis man mestrer overraskelsen, hvis man er forberedt på at blive overrasket, hvis man ved en overraskelse får en horisont, det vi kalder forventningernes horisont (the horizon of expectations), så er der ikke nogen begivenhed, ingen overraskelse. Så de sidste par dage har i høj grad været en overraskende begivenhed for mig, af mange årsager.

Jeg tror at dette er den første konference om Glas. Da jeg havde en række spørgsmål og mange problemer tæt på, var jeg ikke klar til at overveje at der en dag ville være et symposium om lige præcis Glas af de grunde jeg nævnte tidligere. Grunden til dette er at selv de steder i det akademiske liv hvor der findes personer der er venligt stemte mod mig eller mod dekonstruktion, gør Glas modstand mod folk - ikke fordi de finder den dekadent eller afskyelig. (Det er, blandt andre ting, en bog om afsky.) Nej, fordi den er svær at læse, selv for mig. Mine venner bag mig [i.e., panelet] har i løbet af disse to dage kunnet se mig have svært - mere end sædvanligt - ved at tale om bogen fordi den måde bogen er skrevet og komponeret på, gør det svært at nærme sig den og at læse den. Det var derfor en overraskelse for mig at dette symposium skulle finde sted. Jeg vidste at der var en læsegruppe, hvilket er noget andet end et symposium. Men symposiet var en overraskelse og, for mig, en meget lykkelig begivenhed.

Jeg mener at det Hegel-citat hvor han siger »opgaven overrasker/forbavser mig « hentyder til et privat brev hvori han laver korrekturlæsning. Han er i færd med at skrive en bog som han er ved at læse korrektur på. Og jeg 
må sige at historien om denne bog, Glas, om korrekturlæsning, om komposition, etc., var en serie af overraskelser.

Lad mig fortælle en anekdote om den måde bogen blev skrevet som en serie af overraskelser. I 1972 gav jeg et seminar for en gruppe på ti amerikanske studerende om Genet. Vi læste Le journal du voleur (Tyvens Dagbog), og pludselig lagde jeg på den første side mærke til de to ord 'glaviaux', 'glaïeul'. Glaviaux er det franske ord for 'spyt', det er en prøve (a sample); og glä̈eul er en blomst. Jeg lagde altså mærke til disse 'gl' og forsøgte at svare på hvorfor det [i.e., 'gl'] vendte tilbage på den samme side. På samme tidspunkt holdt jeg på mit eget institut et seminar for franske studerende om Hegel, om religion, og jeg begyndte med blomsternes religion - det er et tilfælde. $\mathrm{Og}$ som endnu en overraskelse blev jeg på samme tidspunkt bedt om at bidrage med en nyskreven tekst til et fransk magasin, der var i færd med at udgive et særnummer om mig. Jeg begyndte at skrive med henblik på dette særnummer, og jeg fik den idé at sidestille noget om Genet, glaviaux, glä̈eul - gl, og noget om Hegels blomsterreligion fra seminaret. Således sidestillede jeg to seminarer, og jeg gjorde det med henblik på magasinet. $\mathrm{Og}$ efter at have udgivet denne lille artikel, opstod tanken om at skrive en længere bog, et forsøg på at gennemføre denne Glas; det vil sige at skrive noget om Genet og omarbejde disse to seminarer om Hegel, hvoraf det ene handlede om religion og det andet om familien. Og på den måde fik jeg idéen til at skrive bogen på den særlige måde som den er skrevet: $g l g l$ med Genet, og religion og familien med Hegel.

Men idéen med at skrive i to spalter var ikke ny for mig. Allerede i Dissemination og i den tekst der hedder »The Double Session«, havde jeg forsøgt at sidestille forskellige tekster, forskellige citater, på den samme side - det samme er øvrigt tilfældet med Margins of Philosophy, udgivet i 1972. »Tympan«, en tekst på tre sider, er også skrevet i to spalter, en bred spalte skrevet af mig, og en anden smallere spalte, et langt citat af Leiris - så den blev udgivet som en tekst i to spalter. Men på samme tidspunkt forsøgte jeg også at skrive et essay om Rousseau og Condillac i to spalter, men det mislykkedes, og jeg opgav det. Jeg begyndte at skrive teksten i to spalter på en lille skrivemaskine. Jeg skrev omkring 30-40 sider, men gav derpå op.

Men når jeg ikke kun nævner dette på grund af selvoptaget nostalgi, er det fordi jeg lige siden har følt mig tvunget til at skrive med mere end én stemme.

Jeg har skrevet en række tekster der kæmper mellem en mangfoldighed af steder og stemmer, og den seksuelle forskel er essentiel i denne sammenhæng. Der altid mindst én kvindelig stemme, for eksempel i La vérité en peinture [Sandheden $i$ Maleriet]. Og hele tiden er disse karakterer og signaturer forbundne med mindst én kvindelig stemme. Også i Glas bliver 
spørgsmålet om den seksuelle forskel hele tiden taget op, og jeg tror ikke, at det kun har med det faktum at gøre at Genet var homoseksuel og Hegel heteroseksuel. Jeg tror også at spørgsmålet omkring kvinden, idet moderen ikke udelukkende bliver identificeret med det feminine, havde at gøre med denne deling.

Det næste spørgsmål:

"»3. »Det forhåndenværende arbejdes objekt, og også dets stil, er det lille stykke/den lille bid (morsel)«(Glas 118b). Er stilen i Glas også metoden?«

Nej, stilen er ikke metoden, hvis man ved metode forstår et sæt bevægelser eller normer, en holdning man standhaftigt kan indtage. En metode er et foreløbigt givet sæt af tekniske regler som man forsøger at anvende. En metode er et program, så selv om der findes en række programlignende kontekster, programlignende maskiner i en tekst, er selve det skrevne ikke metodisk eller systematisk.

'Stil' er et interessant og tilbagevendende ord i bogen: på den ene side er Hegel gammeldags; han har en gammeldags måde at skrive på, men mere præcist har han et potent objekt, stylus, og ordet 'stil' bliver behandlet som et billede på (seksuel) potens: stylus, penis, phallus, pen. Noget der var endnu mere svært at oversætte, var ordspillet i det franske disent-ils, "de siger', som for en franskmand kan lyde som 'distil'; og 'distil', som betyder en dobbelt spalte, er faktisk bogens form, dens fremtræden. Dette udtryk, disent-ils, 'de siger', vender tilbage for at hjemsøge bogen mere end én gang.

Desuden er det franske ord stylite en munk der holder til foroven i en spalte. I Genets bog er der en mand ved navn Stylitano, og selvfølgelig er dette forbundet med spørgsmålet omkring fetichen; man kan for eksempel iagttage denne stil (style) på pp. 222-23: „Den pågældende stil, postichen [i.e., det falske, f.eks en paryk] der bliver holdt oppe af blenålen [épingle], er en fetich.« Og derpå spørgsmålet omkring fetichen [p.224]: »Denne skal ikke behandles som en pen.« Og Stylitano bliver af mig kaldt 'the stylite'. Så stilen er et lille stykke af bogen.

Det fjerde spørgsmål:

"Det der eftersøges her, er en trappe der ikke er Hegeliansk, en lidt tosset måde at sige: en anden åndens trappe fra hvilken man kan forstå, klatre op og ned og demontere den Hegelianske kurs [démarche]«(Glas 17a). Efter at have arbejdet så intensivt med at forstå og demontere Hegels 
dialektik, men også med at demonstrere den bemærkelsesværdige sejhed, i Glas og andre steder, hvad bliver der så når alt kommer til alt tilbage af den i dag for dig, her og nu?«

Jeg kan selv sagt ikke besvare dette spørgsmål på en seriøs måde i løbet af nogle få minutter, men det er sandt at Hegel, lige så vel som Platon og andre, vedbliver at være store mestre, og selv om jeg forsøger at diskutere og også dekonstruere det gængse indtryk af Hegel, læser jeg stadig Hegel, og jeg er stadig bevidst om det faktum at det [i.e., Hegels værk] er kraftfuldt, og at jeg er ude af stand til at udtømme Hegels tænkning. Der er altid noget mere, endnu en side af Hegel. Selv i Glas, men også andre steder, forsøgte jeg således at fortolke og dekonstruere en bestemt cirkel af Hegels logik og Hegels position, idet jeg vidste at indeni Hegel er der ressourcer der på en måde ville sætte os i stand til at dekonstruere hans logik. Jeg forsøger at redde Hegel fra Hegel, det vil sige: at bruge Hegel mod Hegel, eller Hegel ved siden af Hegel, eller Hegel uden Hegel, eller Hegel mod Hegel. Der er altså mere end én Hegel. Det er den måde jeg foretrækker at bruge alle de tekster jeg læser på. Jeg er aldrig sikker på at der eksisterer et harmonisk (tekst-)korpus. Det er respektens kendetegn i min tænkning; når jeg læser en tekst, antager jeg at den ikke er så simpel, som den forekommer, og at der findes en heterogenitet, at der er mere end én diskurs indenfor en given diskurs. Og selvfølgelig er der hegemoni, en fremherskende ting hos Hegel. Når vi altså dekonstruerer Hegel, dekonstruerer vi hegemonien i Hegel. Den der dominerer den politiske scene, og den der dominerer i Hegel selv.

Men der er en moder i Hegel, faktisk mere end én moder, og det er grunden til jeg i Glas ikke kun beskæftiger mig med Hegels vigtige tekster, dem vi alle kender, men også med private breve i hvilke han betror nogle ting om sin egen familie, om sine mange problemer i forhold til institutionen. Så Hegel'erne bliver tilbage foran mig, ikke kun forbliver foran mig, men de er bestemt foran mig i form af andre som en uendelig opgave. Men jeg ville sige det samme om en række andre tænkere.

[Derrida fandt sig ikke i stand til at besvare et spørgsmål vedrørende forholdet mellem Glas og Adornos negative dialektik.]

Det sjette spørgsmål:

»»'Jeg skriver for de døde, siger han [Jean Genet] overalt. Læs Brevene til Roger Blin, Alberto Giacomettis Studio, læs alt. Men han siger specifikt: for de døde der aldrig har været i live. Glas-et er for (ing-)en (no one)《 (Glas 78b-79b). Hvem er Glas skrevet for/til? Hvordan opfatter du mod- 
tagerens andethed, hvis der er én modtager, når det gælder det etiske eller det socio-politiske?«

Disse er meget vigtige spørgsmål, men igen er jeg ikke i stand til for alvor at besvare dem. Men lad mig sige dette: Hvordan opfatter jeg modtageren, dennes andethed? Ja, som jeg sagde i begyndelsen, så ved jeg ikke hvem modtageren er. Modtageren er en anden, en politisk anden.

Jeg kan selvfølgelig ikke benægte. at jeg, når jeg skriver, har et billede, eller i det mindste en silhuet, af en mulig modtager eller mulige modtagere. På en måde må bevidstheden være fuld af træk der kommer fra venner, kolleger, en bestemt læser snarere end 'den anden', en lille gruppe af mennesker der udgør det ideelle portræt af den ideelle læser. Men jeg ved at denne læser ikke eksisterer i virkeligheden, og at jeg er nødt til at forsøge at skabe, eller bidrage til at skabe, modtageren.

Modtageren eksisterer altså ikke endnu. Modtageren vil være medunderskriveren (the countersignatory), men den medunderskriver der ikke eksisterer før vedkommende har læst bogen. Modtageren er oplyst og formet af en række andre ting, men også af bogen. Jeg siger ikke hermed, at jeg selv skaber modtageren, men man er nødt til at læse bogen med alle dens tilfældige elementer, alle dens uberegnelige kræfter, alle dens implicitte koder og så fremdeles. Alle bogens potentielle programmer kan måske skabe uforudsigelige læsere, modtagere, og som vi ved, er disse ikke de samme på fransk, dansk, engelsk, tysk, i dag og i morgen; modtagerne af i dag er ikke de samme som de en gang var. Så, jeg ved det ikke. Bogen er fuldstændig som en maskine; den fungerer af sig selv, eller den fungerer ikke af sig selv. Det er umuligt for mig at afgøre.

Se, spørgsmålet er mere specifikt, og vi kan se modtagerens andethed, hvis der altså er en modtager, i forhold til det etiske eller socio-politiske. Når jeg begynder med at sige at jeg ikke kan forudsige eller programmere modtageren, er det ikke blot en anerkendelse af et strukturelt faktum, det er et tegn på respekt: den anden er den anden, hun eller han vil læse idet vedkommende påtager sig sit ansvar, og jeg er ikke kun tolerant over for ham eller hende, men jeg respekterer hans eller hendes signatur på den måde han eller hun læser bogen. Og dette er allerede etisk i sin natur.

Som jeg antydede tidligere, er der en henvendelse der er signeret af mig, et indre valg eller en indre beslutning i bogen. Projektet med at dekonstruere Hegels filosofi med dens politik og det at nævne Hegels anti-jødiskhed er politisk. Jeg ville have sagt dette og udvalgt dette uden at kontrasignere noget i Genets sympati for palæstinenserne. Så der er en vis grad af politisk præference. Nu er det sådan at ingen er tvunget til at være enig, men det er politikkerne. Der er meget af Hegels filosofi i bogen, men 
der er nogle ting der overhovedet ikke er filosofiske, og de har et vist socialt og politisk indhold. Og dette vedrører indholdet. Men det jeg sagde tidligere angående strategien indenfor forlagsverdenen - udgivelsesområdet, med teknologien og så videre - disse valg om at skrive på én måde i stedet for en anden, at forstyrre bogens konventionelle form, bogens linearitet, bogens tegn, og pode den gængse Hegelianske diskurs med Genets uærbødige diskurs; dette er forslaget (eller rettere, et løfte): at jeg er ansvarlig for at underskrive denne bog, når det gælder det faktum at jeg underskriver den.

Det næste spørgsmål:

"»». . . det er nødvendigt at lade tungens glas tavst uddybe sig selv« (Glas 166b). Hører du i adverbiet 'tavst' nogen genklang af hvad Martin Heidegger kalder "stilhedens ringen« (»The Nature of Language« i On the Way to Language 108) eller »stilhedens brag/ringen [peal] « ("Language," i Poetry, Language, Thought 207-08; se også Emmanuel Levinas, Otherwise Than Being 135)?«

Når jeg hører 'tavst', fremkalder det ikke disse tanker i min bevidsthed. 'Tavst' er et meget almindeligt adverbium, og jeg har ikke brug for Heidegger i den forbindelse. Det betyder ikke at jeg ikke tænker på det. Hvis jeg skal vælge referencen i dette tilfælde, stilhed, er det der først melder sig i dette citat, "at lade tungens glas tavst uddybe sig selv": noget man kan høre uden at høre det. I formiddags var netop det at høre noget man ikke hører, midtpunkt for vores diskussion. At høre en stilhed og at tyde eller lade noget virke i stilhed. At lade ordene tale tavst. Hvis jeg skulle vælge en henvisning her, i dag, ville det være nogle ord fra Kongebøgerne i Biblen; det er i forbindelse med Elias. Jeg kender ikke den engelske Kong James version, men det handler om det at vente på Guds tavshed. Der er en række forudsigelser af jordskælv og så videre, og Elias kan ikke høre Guds stemme blandt disse. Og så pludseligt, Hebræisk: at høre stilheden, stemmen af prægtig stilhed, stemmen der er gjort af stilhed. Det er en stemme der taler tavst, og som man kan høre igennem og som stilhed. ${ }^{8}$ Det ville således være den reference jeg ville vælge, snarere end Levinas og Heidegger.

Det sidste spørgsmål:

8. "Men efter ilden kom der en stille, sagte susen.«-Første Kongebog, 19:12. 
"Hvordan skrev du Glas? Kunne den have været udgivet som to adskilte bøger eller ej? Og føler du at den højre spalte, den om Genet, er blevet forholdsvis forsømt?«

Ja, jeg mener at spalten om Genet er blevet forsømt. Af indlysende grunde har den fået mindre opmærksomhed end spalten om Hegel.

Hovedårsagen har at gøre med forholdet til det idiomatiske - den [i.e., Genet-spalten] går tabt, der er flere ordspil, den er mere uoversættelig, mere forbundet med ikke kun det franske idiom, men med fransk slang, så den er i virkeligheden sværere tilgængelig. Spalten om Hegel er svær på en anden måde fordi den er teknisk og så videre, men den følger demonstrationens vedvarende og klassiske proces. Den kunne være et seminar der blev holdt på et universitet. Der er ingen diskontinuitet, den er konventionel, argumenterende med nogle mærkelige momenter, men faktisk er det en ligefrem konventionel, filosofisk diskurs, hvorimod essayet om Genet er diskontinuerligt, det hopper og springer, og har personlig indgriben; derfor er det sværere tilgængeligt. Selve måden jeg skrev spalten om Genet på, er altså en grund til at den har modtaget mindre opmærksomhed, eller mindre synlig opmærksomhed.

Det er svært for en hvilken som helst person at læse de to spalter. Man kan ikke læse dem samtidig. Mit råd ville være først at læse den ene spalte hele vejen igennem, og så den anden spalte, derpå læser man så for anden gang, og så lærer man det udenad! Og hvis man så har en computer, kan man lede efter forbindelser, og efter et stykke tid kan man læse den [bogen], men at læse de to tekster sammen er en umulig opgave.

Hvordan skrev jeg Glas? Kunne de to spalter have været udgivet hver for sig? Nej, selvfølgelig ikke, det ville have gjort at meget var gået tabt. Det ville have været et anderledes og meget mindre interessant værk hvis det var blevet udgivet som to separate spalter. Ikke desto mindre, da den originale udgave blev udgivet som paperback, skilte de ikke de to spalter ad, men satte en spalte på hver side, hvilket jeg selvfølgelig var vred over, men jeg kunne ikke gøre noget fordi udgivere er mere magtfulde end os.

Hvordan skrev jeg Glas - ja, hvordan skrev jeg Glas - jeg fortalte jer om det i begyndelsen. Jeg satte mig ned for at omarbejde de to seminarer, og jeg kiggede på hver eneste side med disse to spalter i tankerne, og fysisk, teknisk, skrev jeg alle spalterne og indskuddene på separate sider på en skrivemaskine: Hegels spalte plus indskuddene på en separat side, og stederne hvor indskuddene skulle være var markerede, det samme med Genet. Og da jeg gav dette til udgiveren, sad vi med lim og saks og satte det sammen, hvilket selvfølgelig var en lang proces. ${ }^{9}$ 
Transskriberet af Dag Petterson og Bent Sørensen, oversat af Joakim Lund og redigeret og kommenteret af redaktorerne.

9. Denne del af arrangementet blev efterfulgt af en runde af spørgsmål fra panelet og salen. 